Accepted: 18.10 .2016

\title{
Effects of Pomegranate (Punica granatum L.) on Paracetamol Induced Acute Hepatic Damage in Mice
}

\author{
Mehmet Ali ERFİDAN ${ }^{1}$, Esra KÜPELİ AKKOL ${ }^{2}$, Alper SEVİMLİ ${ }^{3}$, Turan CİVELEK ${ }^{*}$ \\ ${ }^{1}$ Department of Internal Medicine, Faculty of Veterinary Medicine, University of Afyon Kocatepe, Afyonkarahisar/TÜRKİYE \\ ${ }^{2}$ Department of Pharmacognosy, Faculty of Pharmacy, University of Gazi, Ankara / TÜRKIYYE \\ ${ }^{3}$ Department of Pathology, Faculty of Veterinary Medicine, University of Afyon Kocatepe, Afyonkarabisar/TÜRKIYYE
}

Corresponding author e-mail: tcivelek@aku.edu.tr

\# The research was supported with the project number of 14.SAG.BIL.23 by Kocatepe University Committee of Scientific Research Projects. The presented research was edited from the postgraduate thesis by Mehmet A. Erfidan.

\begin{abstract}
The most common cause of acute liver failure has been reported as paracetamol toxicity. There are some drugs that can be used as an antidote for acetaminophen toxicity, but in some cases these drugs are ineffective. The purpose of this study is to identify protective and side effects of lyophilized extract's from Punica granatum L. in acute liver injury model. In our study, 80 Swiss Albino mice were used. The research was conducted on two main groups. The mice in the side effect group were given pomegranate extracts at 100, 200 and $400 \mathrm{mg} / \mathrm{kg}$ doses. The trial group were administered mentioned doses of extracts and a single dose of paracetamol simultaneously. The results gained from biochemistry analysis demonstrated that lyophilized extract given along with paracetamol caused a significant decrease in serum AST, ALT, TP and TG levels. The pomegranate extract given to the experiment group led to a decrease in RBC, HB, HCT and LYMP levels. Histopathological evaluation demonstrated that the extract alone may cause liver injury ranging from mild to moderate. Yet the extract given simultaneously with paracetamol particularly may have a protective effect on liver in a certain dose of $200 \mathrm{mg} / \mathrm{kg}$ according to biochemistry results and in a certain dose of $400 \mathrm{mg} / \mathrm{kg}$ according to histopathological analysis. Measured AoA levels emphasize the antioxidant activity of the extract for trial group. The results obtained from the side effect group have emphasized possible reducing effect of antioxidant activity of lyophilized extract in mice.
\end{abstract}

Key Words: Acetaminophen, Antioxidant activity, Hepatotoxicity, Hepatoprotective activity, Lythraceae.

\section{Farelerde Parasetamol ile İndüklenen Akut Karaciğer Hasarı Üzerine Narın (Punica granatum L.) Etkileri}

\section{ÖZ}

Parasetamol toksisitesinin akut karaciğer hasarının en önemli nedeni olduğu rapor edilmiştir. Asetaminofen toksikasyonunda antidot olarak kullanılabilen müstahzarlar bulunmakla birlikte, bazı olgularda bu ilaçlar etkisiz kalabilmektedir. Bu çalışmanın amac1, akut karaciğer hasarı modelinde tam meyve liyofilize Punica granatum L. ekstresinin koruyucu etkinliğini ve yan etkilerini ortaya koymaktır. Çalışmada 80 Swiss Albino fare kullanıldı. Araştırma iki ana grup üzerinde yürütüldü. Yan etki grubundaki farelere 100, 200 ve $400 \mathrm{mg} / \mathrm{kg}$ dozunda nar ekstresi verildi. Deneme grubuna ise tek doz parasetamol ile birlikte, eş zamanlı olarak, bahsedilen dozlarda nar ekstresi uyguland. Biyokimya analiz sonuçları parasetamol ile birlikte verilen liyofilize ekstrenin serum AST, ALT, TP ve TG düzeylerinde önemli oranda bir azalmaya neden olduğunu ortaya koydu. Deneme grubunda verilen nar ekstresi ise RBC, HB, HCT ve LENF konsantrasyonlarında bir düşüşe yol açtı. Histopatoloji analiz sonuçları tek başına verilen ekstrenin hafif-orta derecede karaciğer hasarına yol açabileceğini ortaya koydu. Parasetamol ile birlikte eş zamanlı verilen nar ekstresinin, biyokimya sonuçlarına göre, $200 \mathrm{mg} / \mathrm{kg}$ ve histopatoloji sonuçlanına göre ise 400 $\mathrm{mg} / \mathrm{kg}$ dozlarında karaciğer üzerinde koruyucu etkinliği olabileceği belirlendi. Ölçülen AoA düzeyleri, deneme grubu için, verilen ekstrenin antioksidan aktivitesine vurgu yapmaktadır. Yan etki grubundan elde edilen sonuçlar ise farelerde kullanılan tam meyve liyofilize nar suyu ekstresinin antioksidan aktivite etkisini azaltma eğiliminde olabileceğini gösterdi.

Anahtar Kelimeler: Asetaminofen, Antioksidan aktivite, Hepatotoksisite, Hepatoprotektif aktivite, Kunagiller. 


\section{INTRODUCTION}

Paracetamol is a widely used analgesic and antipyretic drug in medicine. It is sold with or without prescription in many countries and widely used (Kittisupamangkol 2009). Being reliable when used in clinical doses paracetamol in high doses cause primarily hepatic as well as renal damages (Larson 2007). The most common cause of acute liver failure has been reported as paracetamol toxicity (Bernal et al. 1998). Lethality occurs when it is taken in a single dose of $300 \mathrm{mg} / \mathrm{kg}$ at once (Alfio et al. 2006).

$\mathrm{N}$-acetylcysteine (NAC) is used as the primary antidote in toxic events occurring from the use of high doses of paracetamol (Mitchelli et al. 1973). However, hepatotoxicity can still develop even when NAC is given (Doyon and Schwartz 2009). Besides, Taraxacum officinale F.H. Wigg, Clitoria ternatea L., Clausena anisata (Willd.) Hook.f., Phyllanthus acidus L. Skeels, Telfairia occidentalis Hook f. are also reported to be protective against liver injuries from paracetamol (Nwanna and Oboh 2007, Jain and Singhai 2011, Nithianantham et al. 2011).

Pomegranate (Punica granatum L.) is one of the oldest fruits. Its antioxidant and radical scavenging activity are well known (Lerman et al. 2005). It was determined that the bioactive substances derived from various parts of pomegranate showed antioxidant, antibacterial, antiviral, antidiabetic, hypolipidemic, hepatoprotective, antineoplastic, antidiarrheal, anthelmintic, and protective activity for vessel and digestive system (Miguel et al. 2010). In spite of worldwide use of pomegranate against various diseases no studies have been found evaluating its paracetamol induced acute hepatic damage. Therefore, in the presented study, the impacts and protective efficiency of pomegranate extract on the liver in the event of acute liver injury induced by paracetamol in mice.

\section{MATERIALS AND METHODS}

\section{Plant Materials}

The pomegranate from the Mediterranean Region (Antalya province) of Turkey formed the plant material of the study.

\section{Preparation of Extracts}

The extract obtained from whole fresh pomegranate fruit by expression technique was frozen at $-80^{\circ} \mathrm{C}$. Then it was dried in lyophilizer and pulverized. The obtained extract was called "lyophilized pomegranate juice extract".

\section{Preparation of Test Samples}

The test samples used had been dissolved into 0.5\% CMC (carboxymethyl cellulose) solution prior to the initiation of the experiment. Test samples were given per os to mice via special gastric gavage at the doses of 100,200 and $400 \mathrm{mg} / \mathrm{kg}$.

\section{Animals}

Male Swiss albino mice (30-40 g) purchased from the animal breeding laboratory of Kocatepe University (Afyonkarahisar, Turkey) were used in the experiments. In the acclimatization process, each major group of mice took place together in conventional cage. In the trial stage, each mouse was housed in a cage as in standard laboratory animal care conditions. During the course of the study, the reach of the mice to water and feed was not restricted. For the purpose of observation, the changes in the health conditions were monitored three times a day.

The presented study was conducted with the approval of Afyon Kocatepe University the Board of Local Ethics for Animal Experiments.

\section{Experimental Model}

The study was carried out on two groups including control (Group 1) and trial (Group 2). Group 1 (only pomegranate extract) and Group 2 were formed by four subgroups. Each subgroup consisted of $n=10$ mice. To the trial group of mice paracetamol and lyophilized pomegranate juice extract (LPE) were given simultaneously. Group 1 was formed by a total number of four subgroups one of which was the positive control group and other three of which were given LPE at the doses of 100, 200, $400 \mathrm{mg} / \mathrm{kg}$ (Table 1). Liver injury in the Group 2 was induced within the model defined by Avlin et al. (2009). With the formation of the model $(500 \mathrm{mg} / \mathrm{kg}$ paracetamol, single dose) single doses of pomegranate extracts in three different doses in gastric lavages were given simultaneously to the mice in Groups 2.2 (500P+100LPE), 2.3 (500P+200LPE) and 2.4 (500P+400LPE) (Table 2). Group 1.1 and Group 2.1 were positive control (PC) groups formed for intergroup comparison. The mice in Group 1.1 (PC1) were given $0.5 \mathrm{ml} /$ single dose of $0.5 \% \mathrm{CMC}$ instead of pomegranate extract and the ones in Group 2.1 (PC2) were given $500 \mathrm{mg} / \mathrm{kg}$ single dose of paracetamol in gastric lavage.

\section{Sampling and Analysis}

Prior to euthanasia blood samples from all groups were taken into plain tubes under anestesia. At the same time, blood samples were taken into EDTA tubes for a complete blood count. Alanine aminotransferase (ALT), aspartate aminotransferase (AST), alkaline phosphatase (ALP), albumin (ALB), total protein (TP), total cholesterol (CHOL) and triglycerides (TG) values of obtained serum samples were measured by a automatic biochemistry analyzer (Cobas C111, Roche, Germany). The haemotological measurement including white blood cell (WBC), red blood cell (RBC), hemoglobin (HB), hemotocrit 
(HCT), platelet (PLT), lymphocytes (LENF) and granulocytes (GRAN) was conducted without delaying the samples by a counter (BC 2800, Mindray, China). Antioxidant activity (AoA) and malondialdehyde (MDA) levels in liver tissue samples were measured. Tissue samples were incubated for $30 \mathrm{~min}$ in boiling water. It was centrifuged at $6000 \mathrm{rpm}$ for $20 \mathrm{~min}$. It was evaluated by spectrophotometric measurement (Thermo Fisher Scientific, Vantaa, Finland). The absorption of the final solution was measured at a wavelength of 532 nm (Calignano et al. 1992).

\section{Histopathological Examination}

The sedation of the mice in each group was performed by Xylazine $(5 \mathrm{mg} / \mathrm{kg})$ and Ketamine (100 mg/kg). Tissue samples were taken for histopathological examination from the animals euthanized by cervical dislocation. Tissue samples in $10 \%$ formaldehyde solution were dispatched to pathology lab. The liver tissue samples detected in $10 \%$ formaldehyde for two days were put into automatic tissue processor (Leica TP1020, Leica Biosystems, Nussloch, Germany) and monitored for 12 hours. The samples were blocked with molten paraffin at $56-58{ }^{\circ} \mathrm{C}$ and those paraffin blocks froze at $-10{ }^{\circ} \mathrm{C}$ in a refrigerator. After $4-5 \mu$ thick sections were sliced the paraffin blocks were stained with hematoxylin eosin. The stained sections were examined under a light microscope. Examining the preparations degeneration and necrosis in the liver were scored as +1 for mild, +2 for moderate and +3 for severe existence.

\section{Statistical Analysis}

To compare Group 1 and Group 2 ANOVA method was applied (Table 1,2,3). For the comparison of the Group 1.1 and Group 2.1. Independent Samples T-Test method was performed (Table 5,6). Statistical analyses were realized with SPSS 13.0 for Windows program $(\mathrm{p}<0.05)$.

\section{RESULTS}

The research data were shown in Tables 1-6. The intergroup comparison performed for Group 1 and Group 2, statistically significance were determined for ALP $(p<0.05)$ and TG $(p<0.05)$ levels in Group 1 and for AST $(p<0.05)$, ALT $(p<0.05)$, TP $(p<0.05)$ and TG $(p<0.05)$ levels in Group 2 (Table 1), moreover, for LYMP $(\mathrm{p}<0.05)$ and MON $(\mathrm{p}<0.05)$ levels in Group 1 and for RBC $(\mathrm{p}<0.05)$, HB $(\mathrm{p}<0.05)$, HCT $(p<0.05)$, LYMP $(p<0.05)$, MON $(\mathrm{p}<0.05)$ levels in Group 2 (Table 2). In the comparison of the control groups a statistically increases was detected in ALB level in Group 2.1 $(p<0.05)$. For the TG value comparison between the control groups the increase in Group 2.1 was statistically significant $(\mathrm{p}<0.05)$ (Table 6$)$. In the comparison between the control groups a severe increase in AST value was detected in Group 2.1 $(\mathrm{p}<0.05)$ (Table 6$)$. In the control group comparison for the TP value the increased in 2.1 was noted as statistically significant $(\mathrm{p}<0.05)$ (Table 6$)$. When the HB level was compared between the control groups the increase in Group 2.1 was statistically important $(\mathrm{p}<0.05)$ (Table 5). In Group 1 comparison the decrease in AoA level in all subgroups was considered statistically meaningful compared to the control group $(p<0.05)$ (Table 3$)$. In the comparison of Group 2 although an increase was observed in all subgroups compared to the control group only the variations in Group 2.3 and 2.4 were statistically significant $(p<0.05)$. In histopathologic examination moderate periacinar necrosis and degeneration occurred in two mice from Group 1.2 and moderate periacinar necrosis and degeneration occurred in five mice from Group 1.3. In Group 1.4 two of the mice suffered from moderate and one from mild periacinar necrosis and degeneration. Severe periacinar necrosis and degeneration was detected in nine mice from Group 2.1, seven mice from Group 2.2 and 2.3 and five mice in Group 2.4 (Table 4).

\section{DISCUSSION}

Paracetamol in high doses causes centrilobular liver necrosis (Alfio et al. 2006). In a study conducted on mice it has been reported that paracetamol in a dose of $300 \mathrm{mg} / \mathrm{kg}$ or above cause severe acute liver necrosis (Douidar et al. 1985). In the presented study, the impact of pomegranate on the liver injury induced by paracetamol was examined.

The rapid increase in the serum ALT level is the most significant indicator of acute liver injury due to paracetamol (Black 1980). On the other hand, serum AST and ALP levels can increase in liver injury and other organ and tissue damages. Therefore, the increase in ALT level must be noted on evaluating the liver injury (Hajimehdipoor et al. 2006). Some researchers as well reported that serum ALT, AST and ALP levels increased in the event of experimental paracetamol toxicity (Kupeli et al. 2006). Similarly, in the presented study it was determined that AST and ALT concentrations were increased by paracetamol to a statistically severe level in trial group. Moreover, a numerical increase was detected in serum ALP level in Group 2. Khalil (2004) reported that giving pomegranate peel extract along with paracetamol to rats did not increase ALT and AST values. Also, in the presented study, serum ALT and AST values in mice which were given specifically $200 \mathrm{mg} / \mathrm{kg}$ dose of lyophilized pomegranate extract were measured at the control group level in Group 1. However, there was a numerically increase but not statistically for all 
subgroups given LPE in Group 1 for AST and ALT levels compared with Group 1.1.

ALB constitutes $50 \%$ of plasma proteins and controls osmotic pressure (Bern et al. 2015). In a toxicity study, it was determined that on being used in female rats in the dose of $60 \mathrm{mg} / \mathrm{kg} /$ day pomegranate extract led to a statistically severe increase in serum ALB concentration (Patel et al. 2008). Kanbur et al. (2009) reported that paracetamol did not have an impact on serum ALB concentration. In our study, no major disparity was detected in serum ALB concentration in Group 2 comparison. As half-life of albumin is long in animals and ALB concentration lowers only in diffuse hepatopathy and porto-systemic shunt (Bern et al. 2015). The model of acute liver injury caused by paracetamol was used in our study and no decrease in serum ALB concentration was detected. In the comparison of the control groups serum ALB level was measured as statistically more severe in Group 2.1 than in Group 1.1. Obtained ALB levels were at the reference range for all groups (Mazzaccara et al. 2008).

In this present study no statistical disparity in serum TP concentration was detected in Group 1. A statistically severe decrease was detected in Groups 2.2 and 2.3 in comparison to the control group. As distinct from the presented report, it was reported that pomegranate increased lowering TP level in the model group (Osman et al. 2011). Mazzaccara et al. (2008) reported serum TP level for male mice as 4.3$6.5 \mathrm{mg} / \mathrm{dl}$. Even though there was a decrease in Group 2.2 and Group 2.3, those values were at reference range for mice in our study. Murali et al. (2012) reported that serum TP levels decreased at a statistically significant ratio in the liver injury by paracetamol ( $1 \mathrm{~g} / \mathrm{kg}$ for 7 days). On the contrary, in the comparison of the control groups within the presented study a statistically significant increase was detected in Group 2.1.

Intergroup analysis results obtained from Group 1 and 2 demonstrated that pomegranate has no effect on serum CHOL level. In contrast to the results presented, reduction and increases have been reported for serum CHOL levels by different research groups. Also reported that whole pomegranate fruit extract did not have an effect on serum TG levels (Patel et al. 2008). Unlike other studies, in our research, the pomegranate extract administered in the dose of $400 \mathrm{mg} / \mathrm{kg}$ increased serum TG concentration in Group 1 at a statistically severe rate. When pomegranate peel extract in the doses of 400 and $800 \mathrm{mg} / \mathrm{kg} /$ day was given to the animals with a high fat diet a statistically severe decrease in TG value was detected (Lei et al. 2007). It was determined in the presented study that the TG value increasing due to paracetamol toxicity lowered at a statistically severe rate when $200 \mathrm{mg} / \mathrm{kg}$ dose of lyophilized pomegranate extract was administered.
Kanbur et al. (2009) reported in th study that acute paracetamol toxicity had no effect on serum TG concentration. In the presented study though paracetamol was found to have increased serum TG concentration at a statistically severe rate.

In the intergroup analysis for WBC value no statistical variation in Group 1 and 2 was detected. Oshida et al. (2008) reported that paracetamol up to the dose of $150 \mathrm{mg} / \mathrm{kg}$ did not influence the WBC value. However, in the presented study, paracetamol in the dose of $500 \mathrm{mg} / \mathrm{kg}$ increased WBC level at a statistically significant rate.

In this research, the antioxidant levels lowered in all subgroups of Group 1 as it increased in all subgroups of Group 2 at a statistically significant rate. Besides the fact that there are several studies presenting the efficiency of the extracts at various polarities that are obtained from juice and various parts of pomegranate. However, the obtained results is not compatible with another (Ashoush et al. 2013). Pomegranate is known to have lowering impact on lipid peroxidation (Matthaiou et al. 2014). MDA is a major biological indicator of lipid peroxidation. Different studies investigated the effects of pomegranate on serum MDA concentration in different periods and found that the use of pomegranate for a period of two weeks or more decrased serum MDA levels at a statistically significant rate (Matthaiou et al. 2014). Moreover, Matthaiou et al. (2014) reported that the use of pomegranate juice for a period of two weeks, serum MDA concentrations did not change. In our study a statistically significant difference was not detected in serum MDA concentrations. The reason for that might have stemmed from the use of whole pomegranate fruit extract in a single dose and short observation period. Our research was finalized at the end of the $12^{\text {th }}$ hour. Ashoush et al. (2013) investigated liver protective efficiency of three different extracts of pomegranate used for 28 days in liver injury by $\mathrm{CCI}_{4}$ and reported that all three extracts lowered MDA concentration. In the presented study no statistical variation was detected in MDA concentrations of Group 2. On the other hand, it was determined that a numerical reduction in all subgroups compared with control groups. That might have been associated with MDA level's not changing due to acute paracetamol toxicity and, pomegranate extract was used in a single dose in this study. Another study reported that paracetamol led to an increase in serum and liver MDA levels in acute liver injury (Kanbur et al. 2009).

Paracetamol in high doses cause to release of $\mathrm{N}$ acetyl-p-benzoquinone imine which is a toxic metabolite in excessive amounts by reducing GSH level (Hinson et al. 2004). Pomegranate, though, increased GSH and its concentrations of antioxidant parameters (Kanbur et al. 2009). It was determined in AoA examination of this study that lyophilized 
pomegranate juice extract in the doses of 100, 200 and $400 \mathrm{mg} / \mathrm{kg}$ performed antioxidant activity found that lyophilized pomegranate juice extract with paracetamol caused a significant increase in AoA levels in Group 2. A dose-dependent increase was determined for sub-groups for trial group.

In the histopathological evaluation of the liver tissue, it was observed that lyophilized pomegranate juice extract caused moderate periacinar necrosis and degeneration in two animals in the dose of $100 \mathrm{mg} / \mathrm{kg}$, moderate periacinar necrosis and degeneration in five animals in the dose of $200 \mathrm{mg} / \mathrm{kg}$ and periacinar necrosis and degeneration occurred mildly in one and moderately in two animals in the dose of $400 \mathrm{mg} / \mathrm{kg}$. That findings are not compatible with the study conducted by Patel et al. (2008). In our study, severe periacinar necrosis and degeneration was only seen in nine animals from the group $500 \mathrm{mg} / \mathrm{kg}$ of paracetamol was given. Periacinar necrosis and degeneration was detected in seven animals from the groups $100 \mathrm{mg} / \mathrm{kg}$ and $200 \mathrm{mg} / \mathrm{kg}$ of lyophilized pomegranate extract with paracetamol were given and periacinar necrosis and degeneration was found only in five animals from the group $500 \mathrm{mg} \mathrm{P}+400 \mathrm{mg} / \mathrm{kg}$ of LPE were given (Table 4). Histopathology results of Group 2 emphasized the positive activity of lyophilized pomegranate juice extract in acute liver injury by paracetamol compared with Group 2.1.

Paracetamol is a cause of severe liver failure (Ranganathan et al. 2006). In this study, whereas lyophilized pomegranate extract with paracetamol most reduced liver injury in the tissue at a certain dose of $500 \mathrm{P}+400 \mathrm{LPE}$ group according to histopathological results, the most significant decline for ALT and AST levels were observed in $500 \mathrm{P}+$ 200 LPE group according to biochemically analysis results. Moreover, LPE caused a dramatic decrease in serum enzymes concentrations in all trial groups depending on the dosage rise but, lower than the control group were measured in Group 1. It was also (Table 1). If these results are considered together, it might be stated that the "active" dosage of lyophilized pomegranate extract is $200 \mathrm{mg} / \mathrm{kg}$ according to biochemistry and histopathological results and $400 \mathrm{mg} / \mathrm{kg}$ according to histopathological analysis results.

\section{CONCLUSIONS}

Consequently, use of a certain dose of lyophilized pomegranate juice extract may be marked in terms of its protective efficiency against acute liver injury caused by paracetamol. It has been determined that the use of $200 \mathrm{mg} / \mathrm{kg}$ of extract with paracetamol for treatment purposes lowers liver enzyme levels dramatically and according to histopathology results leads to a major healing in that dosage of $400 \mathrm{mg} / \mathrm{kg}$. Nevertheless, the liver injury ranging form mild to modarate observed at various rates for all doses in the side effect groups (Group 1) has been considered as a finding indicating that pomegranate might have a toxic impact on liver in mice. But a numerical increases in enzyme levels were observed in Group 1. This condition limits the benefit of the presented study. Within this framework, further similar studies may adapt a new dose-response curve and the doses of whole fruit pomegranate extract given to mice might be reduced, accordingly (i.e.; 25-50-100 $\mathrm{mg} / \mathrm{kg}$. etc.) and to carry out long term observations and predicate hour-based observations such as $12^{\text {th }} \mathrm{h}$ $24^{\text {th }} \mathrm{h} 48^{\text {th }} \mathrm{h}$ on the research plan. And, the different results than expected for AOA and MDA should have led to further investigations on antioxidant properties of LPE. At the same time, it is recommended on Punica granatum may yield fruitful results and isolation of active constituents which may be evaluated as new drug leads.

Table 1: Biochemistry analysis results

Tablo 1: Biyokimya analiz sonuçları

\begin{tabular}{|c|c|c|c|c|c|c|c|c|}
\hline Groups & Dosage (mg/kg) & AST (U/L) & ALT (U/L) & $\operatorname{ALP}(\mathrm{U} / \mathrm{L})$ & $T P(g / d L)$ & $\mathrm{ALB}(\mathrm{g} / \mathrm{dL})$ & CHOL (g/dL) & TG (mg/dL) \\
\hline \multirow[t]{2}{*}{ PC1 } & $\mathrm{CMC}$ & $211.95 \pm 66.08$ & $56.12 \pm 16.17$ & $67.88 \pm 15.95$ & $4.49 \pm 0.12$ & $2.87 \pm 0.11^{\mathrm{a}}$ & $119.24 \pm 3.85$ & $97.57 \pm 12.10^{\mathrm{b}}$ \\
\hline & $100 \mathrm{LPE}$ & $265.85 \pm 60.22$ & $218.59 \pm 163.92$ & $40.06 \pm 7.77$ & $4.28 \pm 0.10$ & $2.61 \pm 0.06^{\mathrm{b}}$ & $110.42 \pm 6.73$ & $139.82 \pm 11.37^{\mathrm{ab}}$ \\
\hline LPE & $200 \mathrm{LPE}$ & $223.95 \pm 46.98$ & $117.23 \pm 38.71$ & $55.62 \pm 4.57$ & $4.49 \pm 0.07$ & $2.97 \pm 0.05^{\mathrm{a}}$ & $105.76 \pm 3.77$ & $106.69 \pm 18.42^{\mathrm{b}}$ \\
\hline (Group 1) & $400 \mathrm{LPE}$ & $304.22 \pm 74.33$ & $82.56 \pm 31.59$ & $69.72 \pm 8.15$ & $4.25 \pm 0.10$ & $2.90 \pm 0.05^{\mathrm{a}}$ & $103.29 \pm 4.39$ & $166.31 \pm 21.93^{a}$ \\
\hline $\mathrm{p}$ & & NS & NS & NS & NS & 0.014 & NS & 0.023 \\
\hline \multirow[t]{2}{*}{ PC2 } & $500 \mathrm{P}$ & $1363.10 \pm 564.97 \mathrm{~b}$ & $1255.10 \pm 658.01^{\mathrm{a}}$ & $90.65 \pm 8.30$ & $5.21 \pm 0.21^{\mathrm{a}}$ & $3.32 \pm 0.12$ & $118.13 \pm 9.24$ & $180.33 \pm 15.99 a$ \\
\hline & $500 \mathrm{P}+100 \mathrm{LPE}$ & $520.17 \pm 113.76^{a b}$ & $95.42 \pm 16.32^{\mathrm{b}}$ & $71.57 \pm 4.78$ & $4.45 \pm 0.13^{b}$ & $3.15 \pm 0.11$ & $104.40 \pm 5.91$ & $143.14 \pm 16.11^{\mathrm{ab}}$ \\
\hline \multirow{2}{*}{$\begin{array}{l}\text { P+LPE } \\
\text { (Group 2) }\end{array}$} & $500 \mathrm{P}+200 \mathrm{LPE}$ & $171.16 \pm 18.68^{\mathrm{b}}$ & $59.54 \pm 5.52^{\mathrm{b}}$ & $65.44 \pm 4.14$ & $4.63 \pm 0.13^{b}$ & $3.07 \pm 0.06$ & $104.38 \pm 6.98$ & $101.40 \pm 17.51^{b}$ \\
\hline & $500 \mathrm{P}+400 \mathrm{LPE}$ & $494.36 \pm 102.91^{\mathrm{ab}}$ & $231.74 \pm 67.37 \mathrm{~b}$ & $72.21 \pm 15.22$ & $4.90 \pm 0.11^{\mathrm{ab}}$ & $3.35 \pm 0.07$ & $99.58 \pm 3.73$ & $171.09 \pm 28.42^{\mathrm{a}}$ \\
\hline \multicolumn{2}{|l|}{$\mathrm{p}$} & 0.047 & 0.016 & NS & 0.017 & NS & NS & 0.033 \\
\hline
\end{tabular}


Table 2: Hematology analysis results

Table 2: Hematoloji analiz sonuçları

\begin{tabular}{|c|c|c|c|c|c|c|c|c|c|}
\hline Groups & Dosage (mg/kg) & WBC $\left(x 10^{9}\right)$ & RBC $\left(\times 10^{12}\right)$ & HB (g/dL) & HCT (\%) & PLT(x109/L) & $\operatorname{LYMP}\left(\times 10^{9}\right)$ & GRAN(x10) & MON(x109) \\
\hline \multirow[t]{2}{*}{ PC1 } & CMC & $4.10 \pm 0.77$ & $9.29 \pm 0.40$ & $12.00 \pm 0.62$ & $37.64 \pm 1.78$ & $843.30 \pm 153.05$ & $2.32 \pm 0.38^{\mathrm{b}}$ & $1.70 \pm 0.37$ & $0.17 \pm 0.04 \mathrm{~b}$ \\
\hline & $100 \mathrm{LPE}$ & $6.83 \pm 1.18$ & $9.06 \pm 0.18$ & $12.79 \pm 0.20$ & $37.27 \pm 0.59$ & $549.70 \pm 94.42$ & $3.77 \pm 0.63^{\mathrm{ab}}$ & $2.75 \pm 0.57$ & $0.31 \pm 0.04^{a}$ \\
\hline \multirow{2}{*}{$\begin{array}{c}\text { LPE } \\
\text { (Group 1) }\end{array}$} & $200 \mathrm{LPE}$ & $7.68 \pm 0.90$ & $9.17 \pm 0.10$ & $13.19 \pm 0.17$ & $38.30 \pm 0.55$ & $913.90 \pm 94.79$ & $4.14 \pm 0.49^{\mathrm{a}}$ & $3.50 \pm 0.47$ & $0.35 \pm 0.04 \mathrm{a}$ \\
\hline & $400 \mathrm{LPE}$ & $6.08 \pm 0.78$ & $9.29 \pm 0.22$ & $13.19 \pm 0.32$ & $38.05 \pm 0.90$ & $611.00 \pm 107.05$ & $2.70 \pm 0.43^{\mathrm{ab}}$ & $3.11 \pm 0.63$ & $0.30 \pm 0.04 \mathrm{a}$ \\
\hline $\mathrm{p}$ & & NS & NS & NS & NS & NS & 0.045 & NS & 0.038 \\
\hline PC2 & $500 \mathrm{P}$ & $7.39 \pm 1.00$ & $10.11 \pm 0.31^{\mathrm{a}}$ & $14.42 \pm 0.48^{\mathrm{a}}$ & $41.11 \pm 1.20^{\mathrm{a}}$ & $660.80 \pm 127.92$ & $3.05 \pm 0.54$ ab & $4.02 \pm 0.61$ & $0.32 \pm 0.05$ \\
\hline \multirow{3}{*}{$\begin{array}{c}\text { P+LPE } \\
\text { (Group 2) }\end{array}$} & $500 \mathrm{P}+100 \mathrm{LPE}$ & $8.99 \pm 1.21$ & $9.59 \pm 0.17 \mathrm{ab}$ & $13.59 \pm 0.24 \mathrm{ab}$ & $38.80 \pm 0.70^{\mathrm{ab}}$ & $803.40 \pm 112.13$ & $2.86 \pm 0.43^{b}$ & $5.37 \pm 0.91$ & $0.49 \pm 0.09$ \\
\hline & $500 \mathrm{P}+200 \mathrm{LPE}$ & $6.79 \pm 0.84$ & $8.95 \pm 0.16^{b}$ & $12.77 \pm 0.19 \mathrm{~b}$ & $36.42 \pm 0.50^{\mathrm{b}}$ & $772.20 \pm 129.07$ & $1.76 \pm 0.25^{b}$ & $4.68 \pm 0.71$ & $0.35 \pm 0.06$ \\
\hline & $500 \mathrm{P}+400 \mathrm{LPE}$ & $7.37 \pm 0.80$ & $9.07 \pm 0.17 \mathrm{~b}$ & $13.46 \pm 0.33 \mathrm{ab}$ & $38.00 \pm 0.87 \mathrm{~b}$ & $786.40 \pm 101.38$ & $4.16 \pm 0.43^{\mathrm{ab}}$ & $2.90 \pm 0.49$ & $0.31 \pm 0.05$ \\
\hline \multicolumn{2}{|r|}{ 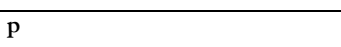 } & NS & 0.002 & 0.013 & 0.005 & NS & 0.004 & NS & 0.045 \\
\hline
\end{tabular}

Table 3: AOA and MDA analysis results

Tablo 3: AOA ve MDA analiz sonuçları

\begin{tabular}{|c|c|c|c|}
\hline Groups & Dosage (mg/kg) & AoA (nmol/L) & MDA (nmol/mL) \\
\hline \multirow[t]{2}{*}{ PC1 } & $\mathrm{CMC}$ & $436.41 \pm 42.59^{a}$ & $1.12 \pm 0.14$ \\
\hline & $100 \mathrm{LPE}$ & $121.02 \pm 44.60^{\mathrm{b}}$ & $0.78 \pm 0.06$ \\
\hline LPE & $200 \mathrm{LPE}$ & $142.93 \pm 53.55^{\mathrm{b}}$ & $0.89 \pm 0.10$ \\
\hline (Group 1) & $400 \mathrm{LPE}$ & $227.97 \pm 104.48^{\mathrm{b}}$ & $0.89 \pm 0.15$ \\
\hline $\mathrm{p}$ & & 0.001 & NS \\
\hline \multirow[t]{2}{*}{ PC2 } & $500 \mathrm{P}$ & $78.89 \pm 47.86^{\mathrm{b}}$ & $0.73 \pm 0.06$ \\
\hline & $500 \mathrm{P}+100 \mathrm{LPE}$ & $276.48 \pm 104.89^{\mathrm{ab}}$ & $0.55 \pm 0.06$ \\
\hline \multirow{2}{*}{$\begin{array}{c}\text { P+LPE } \\
\text { (Group 2) }\end{array}$} & $500 \mathrm{P}+200 \mathrm{LPE}$ & $352.36 \pm 57.94^{a}$ & $0.49 \pm 0.03$ \\
\hline & $500 \mathrm{P}+400 \mathrm{LPE}$ & $421.17 \pm 76.37^{a}$ & $0.67 \pm 0.11$ \\
\hline \multicolumn{2}{|l|}{$\mathrm{p}$} & 0.037 & NS \\
\hline \multicolumn{4}{|c|}{$\begin{array}{l}\text { P; Paracetamol, LPE; Lyophilized pomegranate extract, PC; positive control, AoA; antioxidant activity, MDA; } \\
\text { malondialdehyde. } \\
\text { PC1; Group 1.1., } 100 \text { LPE; Group 1.2., } 200 \text { LPE; Group 1.3., } 400 \text { LPE; Group 1.4., PC2; Group 2.1., } 500 \text { P + } \\
\text { 100 LPE; Group 2.2., } 500 \text { P + } 200 \text { LPE; Group 2.3., } 500 \text { P + } 400 \text { LPE; Group 2.4. }\end{array}$} \\
\hline
\end{tabular}

Table 4: Degeneration and necrosis scores.

Tablo 4: Dejenerasyon ve nekroz skorlar1.

\begin{tabular}{|c|c|c|c|c|c|}
\hline \multicolumn{6}{|c|}{ Score } \\
\hline Groups & Dosage (mg/kg) & $+1(\mathrm{n})$ & $+2(n)$ & $+3(\mathrm{n})$ & n (Total) \\
\hline PC1 & $\mathrm{CMC}$ & 1 & 0 & 0 & 10 \\
\hline \multirow{3}{*}{$\begin{array}{c}\text { LPE } \\
\text { (Group 1) }\end{array}$} & $100 \mathrm{LPE}$ & 0 & 2 & 0 & 10 \\
\hline & $200 \mathrm{LPE}$ & 0 & 5 & 0 & 10 \\
\hline & $400 \mathrm{LPE}$ & 1 & 2 & 0 & 10 \\
\hline PC2 & $500 \mathrm{P}$ & 0 & 0 & 9 & 10 \\
\hline \multirow{3}{*}{$\begin{array}{c}\text { P+LPE } \\
\text { (Group 2) }\end{array}$} & $500 \mathrm{P}+100 \mathrm{LPE}$ & 0 & 0 & 7 & 10 \\
\hline & $500 \mathrm{P}+200 \mathrm{LPE}$ & 0 & 0 & 7 & 10 \\
\hline & $500 \mathrm{P}+400 \mathrm{LPE}$ & 0 & 0 & 5 & 10 \\
\hline
\end{tabular}

P; Paracetamol, LPE; Lyophilized pomegranate extract, PC; positive control, AoA; antioxidant activity, MDA; malondialdehyde.
PC1; Group 1.1., 100 LPE; Group 1.2., 200 LPE; Group 1.3., 400 LPE; Group 1.4., PC2; Group 2.1., 500 P + 100 LPE; Group 2.2., 500 P + 200 LPE; Group 2.3., 500 P + 400 LPE; Group 2.4.

Table 5: Control groups hematology analysis comparisons.

Tablo 5: Kontrol grupları hematoloji analiz sonuçları karşılaştırması.

\begin{tabular}{|c|c|c|c|c|c|c|c|c|}
\hline Groups & $\mathrm{WBC}\left(\mathrm{x} 10^{9}\right)$ & $\operatorname{RBC}\left(\times 10^{12}\right)$ & $\mathrm{HB}(\mathrm{g} / \mathrm{dL})$ & НCT(\%) & $\operatorname{PLT}\left(\times 10^{9} / \mathrm{L}\right)$ & $\operatorname{LYMP}\left(\times 10^{9}\right)$ & $\operatorname{GRAN}\left(\times 10^{9}\right)$ & $\operatorname{MON}\left(\times 10^{9}\right)$ \\
\hline PC1 & $4.10 \pm 0.77$ & $9.29 \pm 0.40$ & $12.00 \pm 0.62$ & $37.64 \pm 1.78$ & $843.30 \pm 153.05$ & $2.32 \pm 0.38$ & $1.70 \pm 0.37$ & $0.17 \pm 0.04$ \\
\hline PC2 & $7.39 \pm 1.00$ & $10.11 \pm 0.31$ & $14.42 \pm 0.48$ & $41.11 \pm 1.20$ & $660.80 \pm 127.92$ & $3.05 \pm 0.54$ & $4.02 \pm 0.61$ & $0.32 \pm 0.05$ \\
\hline $\mathrm{p}$ & 0.018 & NS & 0.007 & NS & NS & NS & 0.005 & 0.045 \\
\hline
\end{tabular}


Table 6: Control groups biochemistry analysis comparisons.

Tablo 6: Kontrol grupları biyokimya analiz sonuçları karşılaştırması.

\begin{tabular}{cccccccc}
\hline Groups & AST(U/L) & ALT(U/L) & ALP(U/L) & TP(g/dL) & ALB(g/dL) & CHOL(g/dL) & TG(mg/dL) \\
\hline PC1 & $211.95 \pm 6608$ & $56.12 \pm 16.17$ & $67.88 \pm 15.95$ & $4.49 \pm 0.12$ & $2.87 \pm 0.11$ & $119.24 \pm 3.85$ & $97.57 \pm 12.10$ \\
PC2 & $1363.10 \pm 565.97$ & $1255.10 \pm 658.01$ & $90.65 \pm 8.30$ & $5.21 \pm 0.21$ & $3.32 \pm 0.12$ & $118.13 \pm 9.24$ & $180.33 \pm 15.99$ \\
p & $\mathbf{0 . 0 3 7}$ & $\mathbf{0 . 0 1 4}$ & NS & $\mathbf{0 . 0 1}$ & $\mathbf{0 . 0 1 9}$ & NS & $\mathbf{0 . 0 0 1}$ \\
\hline
\end{tabular}

$\mathrm{p}<0.05$; NS. not significant. PC1; Group 1.1., PC2; Group 2.1.

\section{REFERENCES}

Alfio B, Anna F, Alessandra O. Paracetamol: New vistas of an old drug. CNS Drug Rev 2006; 12: $250-75$.

Ashoush IS, El-Batawy OI, El-Shourbagy GA. Antioxidant activity and hepatoprotective effect of pomagranate peel and whey powdersin rats. Ann Agric Sci 2013; 58(1): $27-$ 32.

Avlin B, Imaeda AW, Muhammad A, Sohail SM, Mehdi M, Feyyaz S, Sutterwala RA, Flavell WZ. Acetominophen-induced hepatotoxicity in mice is dependent on TIr9 and the Nalp3 inflammasome. J Clin Invest 2009; 119:30514.

Bern M, Sand KMK, Nilsen J, Sandlie I, Andersen JT. The role of albumin receptors in regulation of albumin homeostasis: Implications for drug delivery. J Control Release 2015; 211: 144-62.

Bernal W, Juha W, Mohammed R. Use and outcome of liver transplantation in acetaminophen-induced acute liver failure. Hepatology 1998; 27: 1050-55.

Black M. Acetaminophen hepatotoxicity. Gastroenterology 1980; 78(2): 382-92.

Calignano A, Whittle BJR, Di Rosa M, Moncada S. Involvement of endogenous nitric oxide in the regulation of rat intestinal motility in vivo. Eur J Pharmacol 1992; 229: 273-76.

Douidar SM, Boor PJ, Ahmed AE. Potentiation of the hepatotoxic effect of acetaminophen by prior administration of salicylate. J Pharmacol Exp Ther 1985; 233: 242-48.

Doyon S, Schwartz WK. Hepatotoxicity despite early administration of intravenous $\mathrm{N}$ acetylcystine for acute acetaminophen overdose. Acad Emerg Med 2009; 16: 34-39.

Hajimehdipoor H, Sadeghi Z, Elmi S, Elmi A, Ghazi-Khansari M, Amanzadeh Y. Protective effects of Swertia longifolia Boiss. and its active compound, swerchirin, on paracetamol-induced hepatotoxicity in mice. J Pharm Pharmacol 2006; 58: 277-80.

Hinson JA, Reid AB, McCullough SS, James LP. Acetaminophen-induced hepatotoxicity: role of metabolic activation, reactive oxygen/nitrogen species, and mitochondrial permeability transition. Drug Metab Rev 2004; 36: 805-22.

Jain NK, Singhai AK. Protective effects of phyllanthus acidus (L.) skeels leaf extracts on acetaminophen and thioacetamide induced hepatic injuries in wistar rats. Asian Pac J Trop Med 2011; 4: 470.

Kanbur M, Eraslan G, Neyaz L, Silici S, Liman BC, Altınordu S, Atasever A. The effects of royal jelly on liver damage induced by paracetamol in mice. Exp Toxc Path 2009; 61: 123-32.

Khalil EAM. A hepatoprotective effect of an aqueous extract of pomagranate (Punica granatum L.) rind against acetaminop hen treated rats. EJHM 2004; 16: 112-18.

Kittisupamangkol W. Liver injury from diclofenac or acetaminophen? Am J Gastroenterol 2009; 104: 1862.

Kupeli E, Orhan DD, Yesilada E. Effect of cistus laurifolius L. leaf extracts and flavanoids on acetaminophen-induced hepatotoxicity in mice. J Ethnopharmacol 2006; 103: 455-60.

Larson A. Acetaminophen hepatotoxicity. Clin Liver Dis 2007; 11: 525-48.

Lei F, Zhang XN, Wang W, Xing DM, Xie WD, Su H, Du LJ. Evidence of anti-obesty effects of the pomegranate leaf extract in high-fat diet induced obese mice. Int J Obes (Lond) 2007; 31(6): 1023-29.

Lerman LO, De Nigris F, Williams-Ignarro S. Beneficial effects of pomagranate juice on oxidation-sensitive gensand endothelial nitricoxide synthase activity at sites of perturbedshearsstress. Proc Natl Acad Sci 2005; 102: 4896-901.

Matthaiou CM, Goutzourelas N, Stagos D, Sarafoglu E, Jamurtas A, Koulocheri SD, Haroutounian SA, Tsatsakis AM, Kouretas D. Pomegranate juice consumption increases GSH levels and reduces lipid and protein oxidation in human blood. Food Chem Toxicol 2014; 73: 1-6.

Mazzaccara C, Labruna G, Cito G, Scarfo M, De Felice M, Pastore L, Sacchetti L. AgeRelated reference intervals of the main biochemical and hematological parameters in C57BL/6J, 129SV/EV and C3H/HeJ Mouse strains. Plos One 2008; 3(11): 3772.

Miguel MG, Neves MA, Antunes MD. Pomagranate (Punica granatum L.) a medicinal 
plant with myriad biological properties - a short review. J Med Plants Res 2010; 4: 283647.

Mitchelli JR, Jollow DJ, Potter WZ, Gillette JR, Brodie BB. Acetaminophen-induced hepatic necrosis, IV. Protective role of glutathione. J Pharmacol Exp Ther 1973; 187: 211-17.

Murali A, Ashok P, Madhavan V. Effect of Smilax zeylanica roots and rhizomes in paracetamol induced hepatotoxicity. J Complement Integr Med 2012; 9(1): 1515-53.

Nithianantham K, Shyamala M, Chen Y, Latha LY, Jothy SL, Sasidharan S. Hepatoprotective potential of clitoria ternatea leaf extract against paracetamol induced damage in mice. Molecules 2011; 16: 1013445.

Nwanna EE, Oboh G. Antioxidant and hepatoprotective properties of polyphenol exracts from telfairia occidentalis (fluted pumpkin) leaves on acetaminophen induced liver damage. Pak J Biol Sci 2007; 10: 2682-87.
Oshida K, Iwanaga E, Miyamato-Kuramitsu K, Miyamato Y. An in vivo comet assay of multiple organs (liver, kidney and bone marrow) in mice treated with methyl methanesulfonate and acetaminophen accompanied by hematology and/or blood chemistry. J Toxicol Sci 2008; 33(5): 515-24.

Osman M, Ahmed M, Mahfouz S, Elaby S. Biochemical studies on the hepatoprotective effects of pomegranate and guava ethanol extracts. NY Sci J 2011; 4(3): 27-41.

Patel C, Dadhaniya P, Hingorani L, Soni MG. Safety assessment of pomegranate fruit extract: Acute and subchronic toxicity studies. Food Chem Toxicol 2008; 46: 2728-35.

Ranganathan SS, Sathiadas MG, Sumanasena S, Fernandopulle M, Lamabadusuriya SP, Fernandopulle BM. Fulminant hepatic failure and paracetamol overuse with therapeutic intent in febrile children. Indian J Pediatr 2006; 73(10): 871-75. 